\title{
Microscopic polyangiitis in a case of silica exposure: a rare presentation
}

\author{
Nitesh Gupta, Mahendran A J, Shibdas Chakrabarti, Sumita Agrawal \\ Department of Pulmonary, Critical Care and Sleep Medicine, Safdarjung Hospital, New Delhi, India
}

\begin{abstract}
A 28-year-old male was admitted for breathlessness, haemoptysis, fever and fatigue. The patient had occupational exposure to silica dust. Arterial blood gas test ABG revealed hypoxemic respiratory failure. Chest CT demonstrated ground glass opacities with interlobular septal thickening and small centrilobular nodules with patchy areas of consolidation in bilateral lungs. He was mechanically ventilated for refractory hypoxemia. The treatment with cyclophosphamide and methylprednisolone lead to recovery and extubation. The final diagnosis was diffuse alveolar haemorrhage due to perinuclear antineutrophil cytoplasmic antibody (ANCA)-associated microscopic polyangiitis ( $p$ ANCA-associated MPA). In a tuberculosis endemic country, for patients presenting with diffuse alveolar haemorrhage (DAH), with history of silica exposure, differential diagnosis of ANCA associated vasculitis must be considered.
\end{abstract}

Correspondence: Dr. Sumita Agrawal, Department of Pulmonary, Critical Care and Sleep Medicine, Superspeciality Block, Safdarjung Hospital, New Delhi 110029, India.

Tel. +91.7042336747 .

E-mail: doc.sumitaagrawal@gmail.com

Key words: Vasculitis; respiratory failure; diffuse alveolar haemorrhage.

Contributions: all Authors contributed equally to study conception and design, manuscript drafting, revision and final approval and agree to be accountable for all aspects of the work.

Conflict of interest: the Authors declare no conflict of interest.

Conference presentation: Presented at the National College of Chest Physicians Conference held on 17 February, 2019 at Indian Habitat Centre, New Delhi, India.

Received for publication: 27 April 2019.

Accepted for publication: 30 June 2019.

${ }^{\circ}$ Copyright: the Author(s), 2019

Licensee PAGEPress, Italy

Monaldi Archives for Chest Disease 2019; 89:1087

doi: 10.4081/monaldi.2019.1087

This article is distributed under the terms of the Creative Commons Attribution Noncommercial License (by-nc 4.0) which permits any noncommercial use, distribution, and reproduction in any medium, provided the original author(s) and source are credited.

\section{Case Report}

A 28-year-old male, non-smoker, presented to our emergency with sudden onset breathlessness (mMRC grade 2) and haemoptysis (3 episodes; each with 20-30 ml) for 2 days. He had no wheeze, chest pain and no history of bleeding from any other site. There were no complaints indicative of a connective tissue disorder. There was no past history of similar complaints, history of tuberculosis or contact with a case of tuberculosis. There was no family history of similar complaints. He worked at a stone crushing mill for past ten years. On general physical examination, his respiratory rate was $38 / \mathrm{min}$ and temperature of $37.78^{\circ} \mathrm{C}$. The oxygen saturation at room air was $84 \%$. There was no pallor, clubbing or cyanosis. On auscultation, vesicular breath sounds of equal intensity were audible bilaterally along with fine end-inspiratory crackles in bibasilar areas. Arterial blood gas analysis showed respiratory alkalosis with hypoxemia and wide alveolar-arteriolar gradient $\left(\mathrm{FiO}_{2}: 21 \%\right.$, pH: 7.51; $\mathrm{pCO}_{2}: 29 \mathrm{mmHg} ; \mathrm{pO}_{2}: 46 \mathrm{mmHg}$; $\mathrm{HCO}_{3}: 22 \mathrm{mmol} / \mathrm{L}$ ). Patient was admitted in critical care unit and initiated on high flow oxygen therapy and subsequently intubated and mechanically ventilated due to refractory hypoxemia.

Chest X-ray (Figure 1a), showed coalescent parenchymal alveolar opacities having ill-defined margins and air-bronchogram bilaterally. The haemoglobin, total leucocyte counts and liver function tests were normal. The serology for HIV was negative. The renal function tests showed urea value of $78 \mathrm{mg} / \mathrm{dL}$ and creatinine value of $1.9 \mathrm{mg} / \mathrm{dL}$. The urine analysis showed 20-25 red blood cells (RBCs), 2-4 pus cells, no RBC casts or crystals. Urine protein was $2+$, with spot protein/creatinine ratio of 2.48 , suggestive of moderate proteinuria. Ultrasonography of abdomen was normal. The contrast enhanced/ high resolution computed tomography of the thorax demonstrated ground glass opacities with interlobular septal thickening and small centrilobular nodules with patchy areas of consolidation in bilateral lungs (Figure 1b). The differentials on radiology were acute silico-proteinosis, acute alveolar proteinosis and diffuse alveolar haemorrhage (DAH). Fibreoptic bronchoscopy revealed normal tracheal and bronchial mucosa; the serial aliquots of broncho-alveolar lavage (BAL) fluid did not reveal increasing bloody aspirate or milky effluent. Examination of BAL fluid was negative for acid-fast bacilli (AFB) and the cartridge-based nucleic acid amplification test (CB-NAAT) was negative for tuberculosis (Xpert $M T B / R I F)$. The BAL fluid revealed presence of haemosiderin-laden macrophages. The histopathology of trans-bronchial lung biopsy specimen demonstrated alveolar spaces filled with pigment laden macrophages and RBCs with surrounding fibrosis suggestive of diffuse alveolar haemorrhage (Figure 2a). Thus, renal failure in association with respiratory failure and DAH lead us to provisional diagnosis of pulmonary-renal syndrome. Serum anti-nuclear antibodies (ANA) was negative. The ELISA based peri nuclear-anti-neutrophil cytoplasmic antibody (pANCA) for myelperoxidase (MPO-ANCA) value was positive 91.92 (normal $<20$ ), cytoplasmic-anti-neutrophil 
cytoplasmic antibody (cANCA) directed against proteinase 3 (PR3ANCA) was negative. The patient underwent renal biopsy and treatment with a combination of pulse glucocorticoids and i.v. cyclophosphamide was initiated as per EULAR/ERA-EDTA recommendations for the management of ANCA-associated vasculitis (AAV) [1]. The renal biopsy report demonstrated focal necrotising glomerulonephritis with crescents and fibrinoid tufts, absence of granulomas (Figure $2 b$ ).

The history of respiratory symptoms, laboratory urine analysis and positive MPO-ANCA antibody along with the renal biopsy report were consistent with the diagnosis of microscopic polyangiitis (MPA) in accordance with the 2012 Chapel Hill Consensus Conference definitions for ANCA-associated vasculitis diagnostic criteria [2]. The patient subsequently recovered from respiratory failure in next 3 days and from renal failure within 7 days of $1^{\text {st }}$ dose of pulse cyclophosphamide and corticosteroids. The chest radiograph done after 2 weeks of therapy showed resolution of the alveolar opacities (Figure 3).

\section{Discussion}

Microscopic polyangiitis (MPA) in a person with silica exposure is an uncommon presentation, only eight of such cases have been documented in the literature [1-7] (Table 1). Of these, four had presentation as acute hypoxemic respiratory failure, with diffuse alveolar haemorrhage (DAH) in two such cases. The present case had 10 years exposure to silica, presenting with haemoptysis and acute hypoxaemic respiratory failure, positive serology for $\mathrm{p}$ ANCA and diagnostic renal biopsy, leading to diagnosis of MPA.

Exposure to crystalline silica has been associated with the development of a spectrum of respiratory ailments, including silicosis, progressive pulmonary fibrosis, chronic obstructive pulmonary disease and lung cancer [8]. It has also been related to the development of several other autoimmune diseases, including rheumatoid arthritis (RA), systemic sclerosis (SSc) and systemic lupus erythematosus (SLE). The overall significant summary effect estimate of silica "ever exposure" with development of MPA is OR 3.95, 95\% CI 1.89-8.24 [8].

The pathogenesis of increased risk of AAV in subjects with silica exposure is intriguing. Silica is one of the strongest environmental substances causing overall autoimmunity by two different proposed pathways. Firstly, silica has been shown to cause cell death by necrosis and apoptosis [9]. Secondly, individuals exposed to crystalline silica may have silica particles trapped in their alveoli permanently [10]. Silica is known as a strong $\mathrm{T}$ cell adjuvant and there is activation of both responder and regulatory T-cells leading to autoimmune dysregulation [1]. It is also plausible that free-oxygen radicals produced from silica stimulated-polymorphonuclear lymphocytes (PMN) could trigger a pathway leading to endothelial damage. The interaction with silica and the cell membrane induces the expression of myeloperoxidase on the cell membrane of PMN's and monocytes; its subsequent release could induce an autoimmune reaction characterized by the development of ANCA [2]. Thus, dysregulated immune response triggered in genetically predisposed individuals could induce an uncontrolled systemic inflammatory response, leading to AAV.

Thus, patients with suspected or diagnosed silicosis in a tuberculosis endemic country, presenting with haemoptysis and acute hypoxemic respiratory failure, apart from tuberculosis an aetiology, AAV needs to be considered as a differential. The present case adds to the growing literature on the probable association between MPA and prolonged exposure to silica.

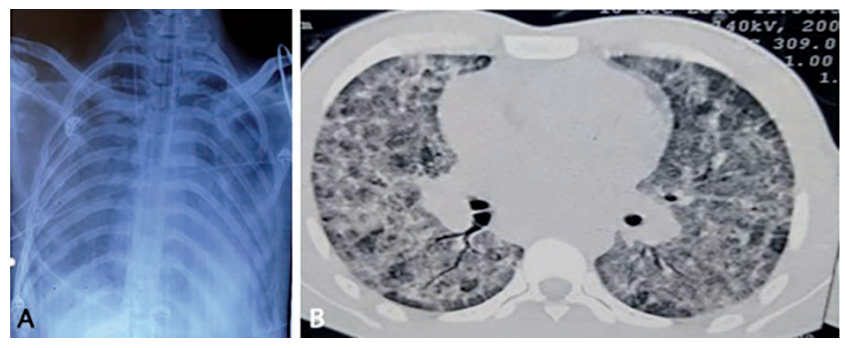

Figure 1. A) Chest X-ray at presentation: coalescent parenchymal alveolar opacities having ill-defined margins and air-bronchogram. B) High resolution computed tomography of the thorax demonstrated ground glass opacities with interlobular septal thickening and small centrilobular nodules with patchy areas of consolidation in bilateral lungs.
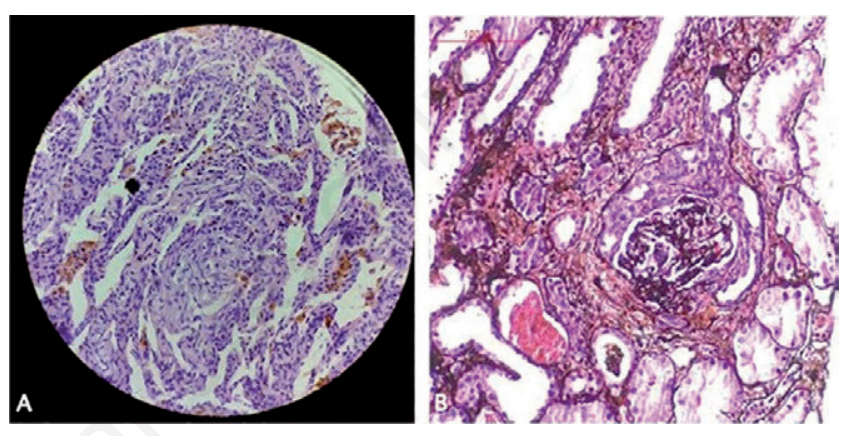

Figure 2. A) Trans-bronchial lung biopsy specimen demonstrated alveolar spaces filled with pigment laden macrophages and RBCs with surrounding fibrosis suggestive of diffuse alveolar hemorrhage. B) Renal biopsy report demonstrated focal necrotizing glomerulonephritis with crescents and fibrinoid tufts, and absence of granulomas (H\&E staining); scale bar: $100 \mu \mathrm{m}$.

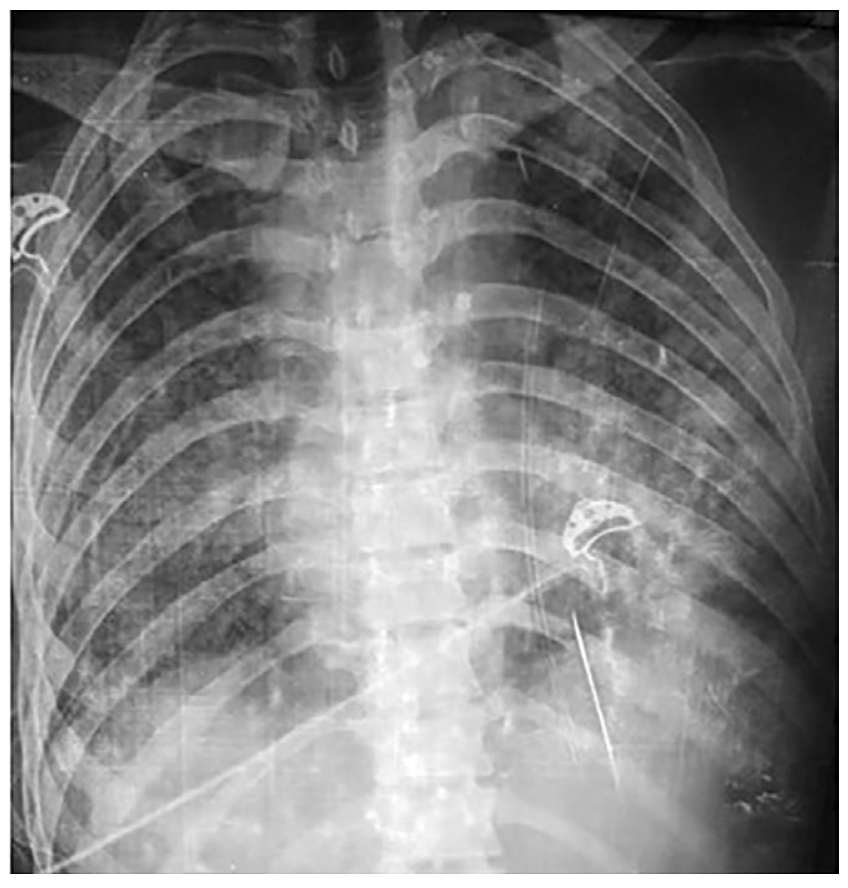

Figure 3. Chest X-ray done after 2 weeks of therapy showed resolution of the alveolar opacities. 
Table 1. Microscopic polyangiitis with silica exposure: the case reports in literature.

\begin{tabular}{|c|c|c|c|c|c|c|c|}
\hline $\begin{array}{l}\text { Age, sex, } \\
\text { reference }\end{array}$ & $\begin{array}{l}\text { Occupation and } \\
\text { duration }\end{array}$ & $\begin{array}{l}\text { Silicosis previously } \\
\text { diagnosed }\end{array}$ & Symptoms & $\begin{array}{l}\text { Pulmonary } \\
\text { complication }\end{array}$ & $\begin{array}{l}\text { Renal } \\
\text { complication }\end{array}$ & Treatment & $\begin{array}{l}\text { Clinical } \\
\text { outcome }\end{array}$ \\
\hline 74 yrs, male [3] & $\begin{array}{l}\text { Shipyard worker, } \\
43 \text { years }\end{array}$ & Yes & $\begin{array}{l}\text { Dry cough, fever, } \\
\text { fatigue pain, } \\
\text { haematuria }\end{array}$ & $\begin{array}{l}\text { Acute hypoxemic } \\
\text { respiratory } \\
\text { failure }\end{array}$ & $\begin{array}{l}\text { Acute renal } \\
\text { failure (RPGN) }\end{array}$ & $\begin{array}{l}\text { Corticosteroids } \\
\text { and } \\
\text { cyclophosphamide }\end{array}$ & Remission \\
\hline 56 yrs, male [4] & $\begin{array}{l}\text { Precious metal } \\
\text { processing, } \\
30 \text { years }\end{array}$ & Yes & Dyspnoea & No & $\begin{array}{l}\text { Acute renal } \\
\text { failure(RPGN) }\end{array}$ & $\begin{array}{l}\text { Corticosteroids, } \\
\text { cyclophosphamide } \\
\text { and haemodialysis }\end{array}$ & Remission \\
\hline 76 yrs, male [5] & Not stated & Yes & Dyspnoea & Pneumothorax & No & $\begin{array}{l}\text { Corticosteroids } \\
\text { and } \\
\text { cyclophosphamide }\end{array}$ & Remission \\
\hline $45 \mathrm{yrs}$, male [6] & Mines, 3 years & No & $\begin{array}{l}\text { Initially fever, } \\
\text { chills and myalgia. } \\
\text { Later dyspnoea } \\
\text { and haemoptysis }\end{array}$ & $\begin{array}{l}\text { Acute hypoxemic } \\
\text { respiratory } \\
\text { failure }\end{array}$ & $\begin{array}{l}\text { Acute renal } \\
\text { failure(RPGN) }\end{array}$ & $\begin{array}{l}\text { Corticosteroids, } \\
\text { cyclophosphamide } \\
\text { and } \\
\text { haemodialysis }\end{array}$ & $\begin{array}{l}\text { Remission, } \\
\text { haemodialysis } \\
\text { continued }\end{array}$ \\
\hline $52 \mathrm{yrs}$, female [6] & Not stated & No & $\begin{array}{l}\text { Fever, chills, } \\
\text { dyspnoea and } \\
\text { haemoptysis }\end{array}$ & $\begin{array}{l}\text { Not stated } \\
\text { failure(RPGN) }\end{array}$ & Acute renal & $\begin{array}{l}\text { Corticosteroids, } \\
\text { Cyclophosphamide } \\
\text { and haemodialysis }\end{array}$ & $\begin{array}{l}\text { Remission, } \\
\text { haemodialysis } \\
\text { continued }\end{array}$ \\
\hline 34 yrs, male [7] & $\begin{array}{l}\text { Marble installer, } \\
6 \text { yrs }\end{array}$ & No & $\begin{array}{l}\text { Malaise, fever } \\
\text { and haemoptysis }\end{array}$ & $\begin{array}{l}\text { Acute hypoxemic } \\
\text { respiratory failure } \\
\text { and DAH }\end{array}$ & $\begin{array}{l}\text { Acute renal } \\
\text { failure(RPGN) }\end{array}$ & $\begin{array}{l}\text { Corticosteroids, } \\
\text { cyclophosphamide } \\
\text { and } \\
\text { plasmapheresis }\end{array}$ & Died \\
\hline 68 yrs, male [11] & $\begin{array}{l}\text { Processing } \\
\text { quartz-containing } \\
\text { stones, } 50 \text { yrs }\end{array}$ & Yes & Fever & Pleural effusion & No & $\begin{array}{l}\text { Corticosteroids, } \\
\text { cyclophosphamide } \\
\text { and } \\
\text { plasmapheresis }\end{array}$ & Remission \\
\hline 68 yrs, male [12] & $\begin{array}{l}\text { Sand-blasting, } \\
10 \text { years }\end{array}$ & No & $\begin{array}{l}\text { Dyspnoea, cough } \\
\text { and haemoptysis }\end{array}$ & $\begin{array}{l}\text { Acute hypoxemic } \\
\text { respiratory failure } \\
\text { and DAH }\end{array}$ & $\begin{array}{l}\text { Acute renal } \\
\text { failure(RPGN) }\end{array}$ & $\begin{array}{l}\text { Corticosteroids } \\
\text { and } \\
\text { cyclophosphamide }\end{array}$ & Remission \\
\hline $\begin{array}{l}28 \text { yrs, male, } \\
\text { current case }\end{array}$ & $\begin{array}{l}\text { Stone crusher } \\
\text { for } 10 \text { years }\end{array}$ & No & $\begin{array}{l}\text { Dyspnoea and } \\
\text { haemoptysis }\end{array}$ & $\begin{array}{l}\text { Acute hypoxemic } \\
\text { respiratory failure } \\
\text { and DAH }\end{array}$ & $\begin{array}{l}\text { Acute renal } \\
\text { failure(RPGN) }\end{array}$ & $\begin{array}{l}\text { Corticosteroids } \\
\text { and } \\
\text { cyclophosphamide }\end{array}$ & Remission \\
\hline
\end{tabular}

\section{References}

1. Yates M, Watts RA, Bajema IM, et al. EULAR/ERA-EDTA recommendations for the management of ANCA-associated vasculitis. Ann Rheum Dis 2016;75:1583-94.

2. Lee S, Hayashi H, Maeda M, et al. Environmental factors producing autoimmune dysregulation - Chronic activation of T cells caused by silica exposure. Immunobiology 2012;217: 743-8.

3. Nishimura Y, Tsuda T, Nishina S, et al. Silicosis, then microscopic polyangiitis-antineutrophil cytoplasmic antibodiesassociated vasculitis may be work-related disease in patients with silicosis. J Gen Fam Med 2017;18:288-90.

4. Lee JW, Myong JP, Choi YJ, et al. Diagnosis of perinuclear anti-neutrophil cytoplasmic antibody-associated microscopic polyangiitis in silicotics: case report. Ann Occup Environ Med 2016;28:21.

5. Ueda M, Arimoto T, Iwasaki Y et al. [A case of microscopic polyangiitis with silicosis].[Article in Japanese]. Nihon Kokyuki Gakkai Zasshi 2011;49:636-41.

6. Baik J, Jeon Y, Chung Y. Two patients with microscopic polyangiitis and unusual pulmonary manifestation. Respirology 2002;7:73-6.

7. Vega Mirand J, Pinto Peñaranda L, Márquez Hernández JD, et al. Microscopic polyangiitis secondary to silica exposure. Reumatol Clin 2014;10:180-2.

8. Gómez-Puerta JA, Gedmintas L, Costenbader KH. The association between silica exposure and development of ANCAassociated vasculitis: systematic review and meta-analysis. Autoimmun Rev 2013;12:1129-35.

9. Pfau JC, Brown JM, Holian A. Silica-exposed mice generate autoantibodies to apoptotic cells. Toxicology 2004;195:167-76.

10. Langley RJ, Kalra R, Mishra NC, et al. A biphasic response to silica: Immunostimulation is restricted to the early stage of silicosis in lewis rats. Am J Respir Cell Mol Biol 2004;30:823-9.

11. Shibuya H, Sano H, Osamura K, et al. Microscopic polyangiitis accompanied by pleuritis as the only pulmonary manifestation of occupational silica exposure. Intern Med 2010;49:925-9.

12. Al-Rajhi A, Brega E, Colman N. Microscopic polyangiitis associated with pleuropericarditis, pulmonary embolism and pulmonary hemorrhage as a complication of silicosis. Resp Med Case Rep 2015;15:106-9. 
